\title{
Studi Kasus Kebiasaan Belajar dan Self Management pada Anak Pekerja Migran
}

\author{
Irma Lia Mutiara ${ }^{1}$, Blasius Boli Lasan ${ }^{1}$, Triyono ${ }^{1}$ \\ ${ }^{1}$ Bimbingan dan Konseling-Universitas Negeri Malang
}

\begin{tabular}{l} 
INFO ARTIKEL \\
\hline Riwayat Artikel: \\
Diterima: 02-10-2019 \\
Disetujui: $14-04-2020$ \\
\hline
\end{tabular}

Kata kunci:

study habits; self management;

the child of a migrant worker; kebiasaan belajar; self management; anak pekerja migran

\begin{abstract}
ABSTRAK
Abstract: The purpose of this research was to. Learning Habits and Self Management of Children of Low-achieving Migrant Workers in Elementary School Students in Ponorogo. This research uses a qualitative approach to the type of case study. The result shows that the learning achievement of migrant workers' children was influenced by several factors namely there were four aspects of learning habits including how to take lessons, how to study independently, how to study groups and how to study textbooks. While self-management of migrant workers' children is obtained 3 (three) aspects, they are self-encouragement, self-care and self-control. Another factor influencing the learning habits and self-management of migrant worker children is the giving of attention and affection from the family which causes children to tend to be passive. Implications of Learning Habits and Self-Management of Knowledge. workers' children in four areas of guidance and counseling namely the private field is able to regulate themselves, willingness of discipline, and have a sense of responsibility. In the social field, namely developing women to socialize and communicate with their environment, the habit of manners is high. Counselors help students to choose and determine future careers according to students' talents and self-interest. The last field is learning by providing tutoring services to students in order to obtain effective study habits to develop students' curiosity in adding knowledge.
\end{abstract}

\begin{abstract}
Abstrak: Penelitian ini bertujuan untuk mengertahui cara belajar dan self management anak pekerja migran berprestasi renda pada siswa sekolah dasar di Ponorogo. Penelitian ini menggunakan metode kualitatif jenis studi kasus. Hasil analisa menunjukkan bahwa prestasi belajar anak pekerja migran dipengaruhi oleh empat aspek kebiasaan belajar, meliputi cara mengikuti pelajaran, cara belajar mandiri, cara belajar kelompok, dan cara mempelajari buku teks. Self management pada anak pekerja migran diperoleh tiga aspek, yaitu pendorong diri, penyususn diri, dan pengendalian diri. Faktor lain yang memengaruhi kebiasaan belajar dan self management anak pekerja migran adalah pemberian perhatian dan kasih sayang dari keluarga yang menyebabkan anak cenderung bersifat pasif. Implikasi Kebiasaan Belajar dan Self Management anak pekerja migran pada empat bidang bimbingan dan konseling, yaitu bidang pribadi mampu mengatur diri, kemauan disiplin, dan memiliki rasa tanggung jawab. Pada bidang sosial yaitu mengembangkan kemampuan bersosial dan berkomunikasi dengan lingkungannya, menjunjung tinggi kebiasaan sopan santun. Konselor membantu siswa untuk memilih dan menentukan karir di masa mendatang sesuai dengan bakat dan minat diri siswa. Bidang terakhir yaitu bidang belajar dengan memberikan layanan bimbingan belajar kepada siswa guna memperoleh kebiasaan belajar yang efektif untuk mengembangkan rasa ingin tahu siswa dalam menambah pengetahuan.
\end{abstract}

\section{Alamat Korespondensi:}

Irma Lia Mutiara

Bimbingan dan Konseling

Universitas Negeri Malang

Jalan Semarang 5 Malang

E-mail: mutiarairmalia@gmail.com

Berdasarkan data pekerja migran Indonesia di Badan Nasional Penempatan dan Perlindungan Tenaga Kerja Indonesia (BNP2TKI) banyaknya pekerja migran di Indonesia merupakan fenomena yang tidak asing lagi kita dengar dan setiap tahunnya mengalami peningkatan. Jumlah pekerja migran di wilayah Jawa Timur sekitar 75.000 orang di tahun 2017. Jumlah pekerja migran yang mayoritas perempuan sebanyak 80,56 persen dan laki-laki sebesar 19,48 persen. Pada bulan Mei 2018, penyumbang pekerja migran terbanyak adalah wilayah Jawa Timur sebesar 28.899 orang. Dalam data BNP2TKI sebanyak 4.095 jiwa berasal dari Ponorogo bekerja sebagai pekerja migran. Pekerja migran di Ponorogo semakin meningkat dari tahun ke tahun. Pada tahun 2017 berjumlah 883 jiwa, 2018 berjumlah 849, tahun 2019 sampai bulan Mei berjumlah 708 jiwa. 
Saat ini, pendidikan di Indonesia berusaha untuk mencapai mutu pendidikan yang bagus. Belajar memberikan tanggung jawab dengan tekun kepada siswa, seperti kebiasaan dalam belajar, cara belajar yang efektif, mengelola diri, kesadaran diri, kecakapan, dan berkepribadian yang baik. Siswa dituntut wajib belajar agar mencapai prestasi yang diinginkan. Pendidikan tersebut juga mampu diperoleh dari berinteraksi dengan orangtua (pendidikan keluarga). Orangtua memiliki peran besar dalam pendidikan anak yang dapat memengaruhi prestasi belajarnya. Rendahnya prestasi belajar yang dialami oleh anak pekerja migran tidak hanya disebabkan oleh rendahnya inteligensi yang mereka miliki, walaupun memiliki rencana belajar yang baik jika terdapat sikap malas dalam belajar maka hal itu hanyalah sebuah rencana. Sama halnya yang dialami siswa Sekolah Dasar di Josari 02, yaitu kesulitan dalam mengelola diri yang disebabkan oleh beberapa faktor, yaitu kurangnya motivasi belajar pada anak dan perhatian orangtua. Hal tersebut menjadikan prestasi belajar anak rendah.

Masalah yang dihadapi anak di sekolah, keluarga, hubungan dengan orang lain, dan masalah pada diri sendiri. Ketika anak hidup bersama orangtua dijadikan ketauladanan bagi anak dalam kehidupan beragama dan anak cenderung memiliki prestasi yang baik karena selalu mendapatkan kontrol dari orangtua dalam belajar. Selain itu, faktor ekonomi juga memiliki keterkaitan dengan prestasi belajar karena sarana dan prasarana yang disediakan orangtua secara memadai untuk menunjang proses belajar. Masalah yang dihadapi anak memerlukan penanganan agar anak mampu mengelola diri serta memiliki model cara belajar yang efektif karena sukses tidaknya anak ditentukan oleh relasi diri pada individu itu sendiri. Semakin banyak kontrol yang dimiliki individu, semakin banyak pula bertindak positif (Daradal, 2010). Seorang ibu yang biasanya dijadikan panutan serta mampu memberikan perhatian lebih kepada anaknya ketika terdapat jarak di antara mereka mampu menimbulkan tekanan pada anak yang berakibat pada perubahan pada kebiasaan karena terpisahnya dengan figur yang lekat dengan anak.

Fenomena ketidakhadiran seorang ibu pada sebuah keluarga banyak dialami oleh anak usia sekolah dasar yang berada di pedesaan Ponorogo. Masyarakat bekerja di luar negeri karena kebutuhan biaya hidup yang meningkat mereka memilih bekerja jauh dari keluarga karena jika bekerja di rumah dengan pendidikan yang terbatas mereka hanya dapat bekerja sebagai buruh tani, serabutan, dan buruh bangunan yang gajinya tidak seberapa dengan bekerja sebagai pekerja migran meski beresiko jauh dari keluarga serta perkembangan anak yang kurang perhatian seorang ibu, di sini Ayah serta keluarga lain memiliki peran yang penting dalam perkembangan anak, dengan mengasuh serta memotivasi anak dalam belajar. Hal ini memerlukan kajian lebih lanjut. Kesejahteraan anak ditujukan untuk menjamin terpenuhinya kebutuhan pokok anak.

Kasus yang ditangani oleh peneliti di Sekolah Dasar di Josari yaitu terkait kebiasaan belajar anak pekerja migran yang memiliki prestasi rendah, Salah satu sekolah di wilayah Ponorogo, kecamatan Jetis, desa Josari, dusun Keben, dimana letak desa tersebut merupakan wilayah pinggiran dengan hamparan persawahan dan akses jalan yang kurang memadai, serta perekonomian yang rata-rata menengah ke bawah, pekerjaan Ibu yang sebagian besar bekerja sebagai pekerja migran dan Ayahlah yang memiliki peran ganda dalam merawat anaknya. Anak-anak di wilayah Josari lebih banyak mendapatkan kasih sayang dari seorang ayah dan keluarga terdekatnya seperti nenek di bandingkan dengan Ibunya, mereka di didik oleh Ayah sehingga seorang anak kurang mendapatkan motivasi dalam belajar karena ayah kurang memberikan motivasi serta dukungan dalam perkembangan prestasi anak di sekolah, selain merawat anak di rumah, ayah juga dituntut untuk bekerja sebagai buruh tani di lingkungannya. Hal ini menjadikan ayah kurang memperhatikan anak. Di lingkungan ini juga terdapat tempat les privat anak-anak, tetapi beberapa siswa mereka lebih memilih belajar sendiri di rumah daripada ikut les privat untuk penambahan materi belajar karena dirasa sudah kelas tinggi mampu belajar sendiri di rumah.

Berdasarkan fenomena tersebut penelitian ini bertujuan untuk melihat kebiasaan belajar anak dan self management anak-anak SDN 02 Josari yang memiliki latar belakang sebagai anak pekerja migran dengan prestasi rendah. Penelitian ini di rasa penting untuk diteliti oleh jurusan bimbingan dan konseling karena saat ini ranahnya BK tidak hanya ada di SMP dan SMA, sekolah dasar juga memerlukan adanya guru bimbingan konseling untuk membantu guru kelas dalam menyelesaikan permasalahan siswa. Teknik yang sesuai dengan permasalahan anak sekolah dasar terutama pada kasus anak pekerja migran yaitu dengan adanya konselor kunjung (Trusty, Mellin, \& Herbert, 2008).

Beberapa cara yang peneliti gunakan untuk memperoleh data cara belajar anak dengan cara mengamati secara langsung cara belajar anak ketika berada di sekolah dan di rumah guna memperoleh data yang akurat. Peneliti juga mencari data dari berbagai sumber dari keluarga, teman, guru, lingkungan, tetangga sekitar untuk menanyakan keterkaitan data yang diperlukan peneliti. Ketika di lapangan peneliti akan terlibat langsung dengan keluarga siswa, pada pertemuan pertama peneliti akan menemui keluarga pekerja migran untuk meminta izin serta menyampaikan tujuan kedatangannya. Pada pertemuan kedua peneliti akan mengakrabkan diri dengan keluarga berbincang ringan serta mengamati lingkungan sekitar anak, peneliti juga sudah menentukan target yang akan dijadikan sumber data tambahan. Pertemuan ketiga agar peneliti lebih akrab dengan keluarga peneliti akan sering berkunjung kerumah anak untuk silaturrahmi serta memperdalam data penelitian. Penelitian ini tentu berbeda dari penelitian sebelumnya. Penelitian yang dilakukan oleh penulis mengkaji terkait kebiasaan belajar anak pekerja migran usia sekolah dasar di Josari yang memiliki prestasi rendah. Penulis tertarik untuk mengkaji masalah tersebut secara mendalam dalam penelitian. 


\section{METODE}

Penelitian ini menggunakan pendekatan kualitatif jenis studi kasus mendalam. Dalam Penelitian ini peneliti memposisikan diri sebagai pengamat dalam aktivitas belajar siswa di sekolah maupun di rumah. Penelitian dilaksanakan di sekolah dasar negeri yang berlokasi di Dusun Keben, Desa Josari, Kecamatan Jetis, Kabupaten Ponorogo, Provinsi Jawa Timur pada bulan Juni sampai Agustus 2019. Subjek dalam penelitian ini adalah anak TKW berprestasi rendah yang diasuh oleh orangtua tunggal yaitu Ayah, anak berusia 9-12 tahun yang ditinggalkan Ibunya dalam kurun waktu lebih dari 2-3 tahun.

Jumlah siswa keseluruhan pada tahun ajaran 2019/2020 di Sekolah Dasar Josari 02 berjumlah 59 siswa. Jumlah tersebut tidak banyak dikarenakan sekolah terletak di pinggiran dan SDM yang kurang memadai. Dalam satu sekolah terdapat hampir 50\% siswa berstatus sebagai anak pekerja migran. Setelah melihat data awal di sekolah, pada siswa kelas V di Sekolah Dasar Josari 02 jumlah anak dalam satu kelas yaitu tujuh siswa dengan empat siswa yang berstatus anak pekerja migran. Pada siswa kelas VI dari 15 jumlah siswa dalam satu kelas terdapat delapan siswa sebagai anak buruh migran.

Sumber data yang peneliti gunakan yaitu data primer dan sekunder. Data primer diperoleh secara langsung dari siswa yang berstatus sebagai anak pekerja migran berprestasi rendah. Data primer tersebut dikumpulkan dengan mewawancarai secara mendalam dan observasi partisipasi karena peneliti ingin terlibat langsung dalam kehidupan belajar anak pekerja migran berprestasi rendah, baik di lingkungan sekolah, maupun di lingkungan rumah sehingga peneliti mendapatkan data yang akurat dan objektif. Data sekunder dijadikan sebagai data pendukung data primer, yaitu orangtua, guru, teman, kepala sekolah, keluarga migran, dan dokumen yang diperlukan dalam penelitian. Dalam pengumpulan data peneliti mengumpulkan data dengan wawancara, observasi, dan dokumentasi. Penelitian ini bermaksud untuk mengembangkan eksplorasi mendalam terhadap fenomena. Jadi, untuk memahami fenomena tersebut peneliti sengaja memilih tempat dan individu guna membantu peneliti dalam memahami fenomena untuk mengembangkan pemahaman yang terperinci. Peneliti menggunakan purposive sampling tipe Confirming and Disconfirming Sampling, purposeful pada tipe ini adalah untuk mengonfirmasi temuan pendahuluan peneliti perlu mengambil sampel tempat atau individu. Pada penelitian ini uji keabsahan akan di uji melalui triangulasi dengan dosen pembimbing, kepala sekolah/Guru SD, orangtua, tetangga, dan lingkungan yang memahami objek secara mendalam guna memperoleh interpretasi di luar interpretasi peneliti untuk meminimalisir bias peneliti dalam menafsirkan data, agar keabsahan dan kevaliditasannya dapat dipertanggungjawabkan oleh peneliti.

Berkaitan dengan penelitian ini, pendekatan studi kasus dianggap lebih sesuai karena menggunakan multisumber. Adapun teknik analisis data menurut (Creswell, 2015) beberapa langkah dalam menganalisis dan menginterpretasi data kualitatif untuk perolehan data dapat diilustrasikan sebagai berikut. Pertama, mengorganisasi data mentah berupa catatan lapangan, rekaman hasil wawancara, foto, dokumen sekolah dikumpulkan. Kedua, mengambil data menurut partisipan, tempat lokasi yang telah diberi kode. Ketiga, mendeskripsikan apa yang dipelajari dan mengembangkan tema, ide secara luas dari data yang diperoleh. Keempat, mempresentasikan dan melaporkan temuan. Hal ini memerlukan pemaparan beberapa temuan dalam bentuk tabel dan gambar serta mengonstruksikan suatu naratif untuk menjelaskan apa yang telah peneliti temukan sebagai jawaban. Kelima, menginterpretasi temuan. Peneliti melangkah mundur dan membentuk makna lebih besar tentang fenomena yang diteliti berdasarkan pandangan pribadi, perbandingan dengan penelitian terdahulu/kajian teori. Keenam, peneliti menentukan keakuratan atau kreadibilitas temuan melalui strategi triangulasi.

\section{HASIL}

Hasil dari penelitian ini berupa temuan beberapa aspek kebiasaan belajar dan self management anak pekerja migran berprestasi rendah dan beberapa data penemuan diantaranya jumlah anak pekerja migran di sekolah dasar 02 Josari pada tahun ajaran 2019/2020 yang disajikan pada tabel 1.

Tabel 1. Jumlah Siswa Berstatus sebagai Anak Pekerja Migran

\begin{tabular}{|c|c|c|c|c|}
\hline No & Uraian & Detail & Jumlah & Total \\
\hline \multirow{2}{*}{1} & \multirow{2}{*}{ Kelas 1} & $\mathrm{~L}$ & 4 & \multirow{2}{*}{4} \\
\hline & & $\mathrm{P}$ & 0 & \\
\hline \multirow{2}{*}{2} & \multirow{2}{*}{ Kelas 2} & $\mathrm{~L}$ & 0 & \multirow{2}{*}{1} \\
\hline & & $\mathrm{P}$ & 1 & \\
\hline \multirow{2}{*}{3} & \multirow{2}{*}{ Kelas 3} & L & 2 & \multirow{2}{*}{7} \\
\hline & & $\mathrm{P}$ & 5 & \\
\hline \multirow{2}{*}{4} & \multirow{2}{*}{ Kelas 4} & $\mathrm{~L}$ & 1 & \multirow{2}{*}{1} \\
\hline & & $\mathrm{P}$ & 0 & \\
\hline \multirow{2}{*}{5} & \multirow{2}{*}{ Kelas 5} & $\mathrm{~L}$ & 1 & \multirow{2}{*}{4} \\
\hline & & $\mathrm{P}$ & 3 & \\
\hline \multirow{2}{*}{6} & \multirow{2}{*}{ Kelas 6} & $\mathrm{~L}$ & 5 & \multirow{2}{*}{8} \\
\hline & & $\mathrm{P}$ & 3 & \\
\hline \multicolumn{4}{|c|}{ Total } & 25 \\
\hline
\end{tabular}


Jumlah siswa yang terdaftar sebagai anak pekerja migran di SDN 02 Josari berjumlah 25 siswa dari jumlah keseluruhan 59 siswa. Artinya, terdapat $42 \%$ orangtua siswa yang bekerja sebagai pekerja migran dan $58 \%$ orangtua siswa bekerja sebagai buruh dan petani di lingkungan rumah. Orangtua dari anak pekerja migran sebagian besar menekuni pekerjaan kasar guna memenuhi kebutuhan. Banyaknya jumlah anak pekerja migran di sekolah tersebut karena dipengaruhi oleh keadaan lingkungan di desa Josari yang mayoritas wanita di desa tersebut bekerja di luar negeri sejak usia remaja sampai berkeluarga. Sehingga menjadikan jumlah anak pekeja migran di sekolah tersebut meningkat setiap tahunnya.

Berdasarkan paparan data penelitian maka langkah selanjutnya adalah membuat kategorisasi untuk mendapatkan temuan penelitian. Adapun hasil data tersebut menghasilkan temuan berupa gambaran kebiasaan belajar anak pekerja migran sebagaimana ditunjukkan pada gambar 1 .

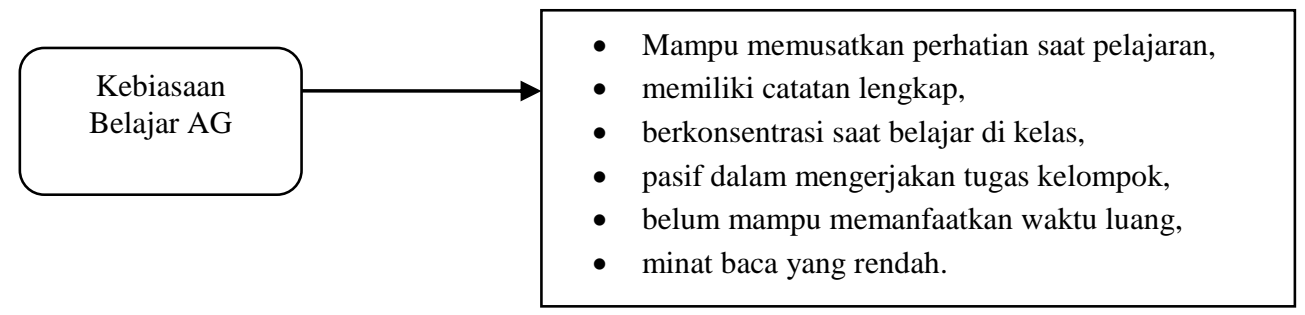

\section{Gambar 1. Aspek Kebiasaan Belajar AG}

Berdasarkan hasil paparan data, ditemukan beberapa ciri kebiasaan belajar dari anak pekerja migran. Subjek AG memiliki kebiasaan belajar, yaitu (1) mampu memusatkan perhatian saat pelajaran, (2) memiliki catatan lengkap, (3) berkonsentrasi saat belajar, (4) pasif dalam mengerjakan tugas kelompok, (5) belum mampu memanfaatkan waktu luang, dan (6) minat baca yang rendah.

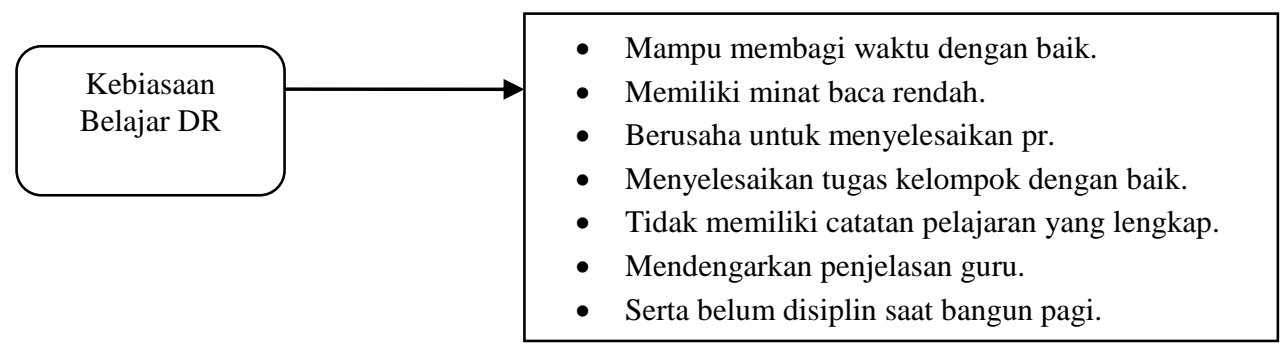

Gambar 2. Aspek kebiasaan Belajar AG

Temuan penelitian kebiasaan belajar juga terkait dengan upaya self management dari kedua subjek. Berdasarkan temuan di lapangan menunjukkan bahwa adanya keterkaitan antara self management dan kebiasaan belajar anak pekerja migran pada proses belajarnya yaitu memiiki kebiasaan belajar yang tidak teratur, kurangnya kemauan membaca buku pelajaran, serta kurang nya konsentrasi anak saat belajar di rumah, anak TKW belum dapat memanfaatkan waktu luangnya untuk belajar, menjadikan anak pekerja migran kurang mampu dalam mengatur self management pada aspek pendorong diri dan pengendalian diri yang berpengaruh pada prestasi belajarnya. Berikut paparan data berdasarkan temuan peneliti terkait self management AG dan DR (Gambar 3). Adapun gambaran self management pada DR dapat dilihat pada gambar 4.

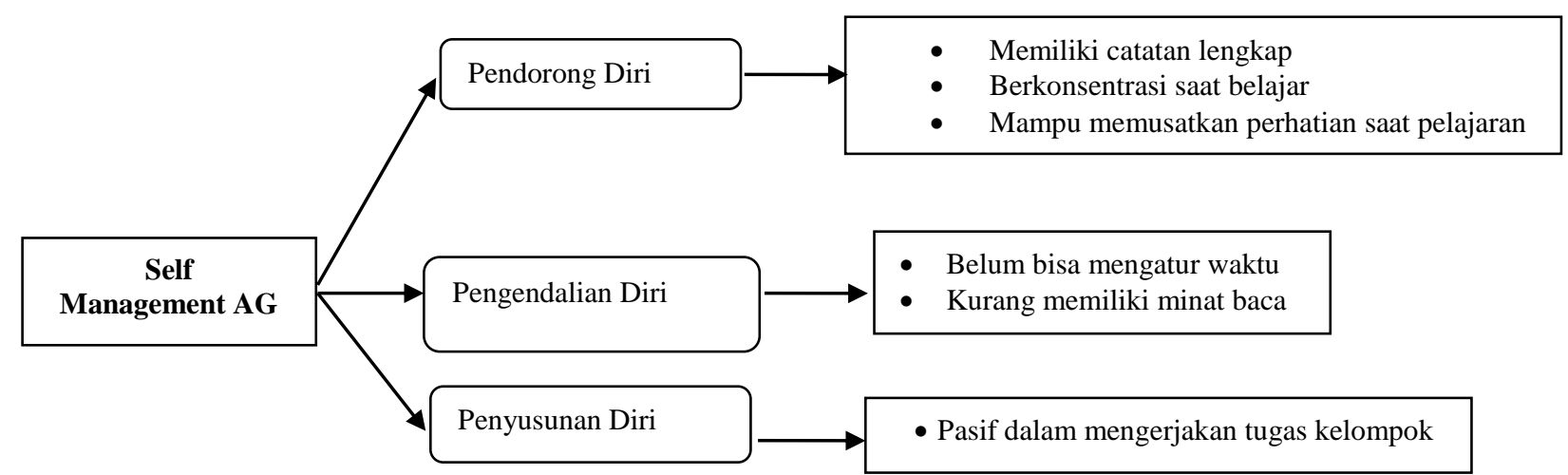

Gambar 3. Aspek Self Management AG 


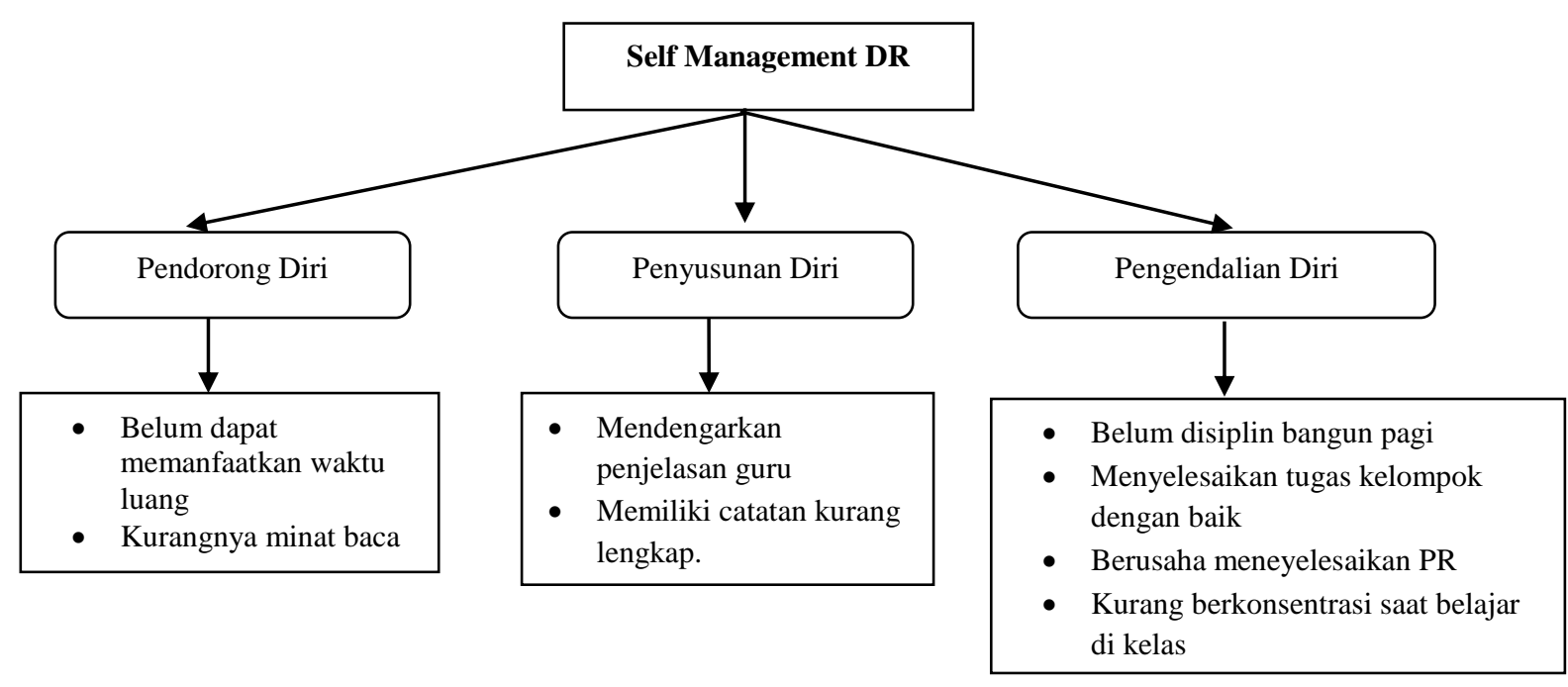

\section{Gambar 4. Aspek Self Management DR}

\section{PEMBAHASAN}

Kebiasaan belajar dan self management anak pekerja migran berprestasi rendah di sekolah dasar Ponorogo didasarkan pada empat aspek. Pertama, cara mengikuti pelajaran, belajar yang efektif dengan cara merangsang mood, menumbuhkan minat, dan memotivasi diri (Widiarsono, 2017). Minat dalam belajar merupakan rasa suka pada sesuatu tanpa ada yang menyuruh dan berkembang sesuai dengan keinginan siswa dalam aktivitas belajar. Pernyataan lain dari (Miftahur, 2015) yaitu selama proses pembelajaran, guru hendaknya meningkatkan kemampuan siswa pada bidang kognitif, afektif, dan psikomotorik, agar semua bidang dapat terlaksana diperlukan minat dan perhatian siswa dalam proses belajar. Hasil penelitian (Limpo, Oetomo, \& Suprapto, 2013) menyebutkan bahwa lingkungan kelas memiliki pengaruh yang signifikan pada sikap siswa terhadap pelajaran, hal lain yang berpengaruh besar selain lingkungan kelas adalah faktor guru dan teman sebaya. Kedua, cara belajar mandiri, DR adalah siswa yang memiliki prestasi rendah di kelasnya (Magfiroh, Rahman, \& Sulateri, 2015) yang menyatakan bahwa kebiasaan belajar tidak sepenuhnya mempengaruhi hasil belajar ini disebabkan oleh keadaan ekonomi orangtua, perhatian dan kasih sayang dan kelemahan kecerdasan yang siswa miliki. Sejalan dengan pendapat (Megayanti, 2016), anak malas disebabkan oleh faktor intrinsik dan ekstrinsik. Ketiga, cara belajar kelompok, AG memiliki kebiasaan belajar kelompok yang pasif, padahal variasi pada belajar siswa sangat diperlukan agar siswa tidak bosan. Variasi dalam belajar agar individu mendapatkan motivasi untuk belajar dengan belajar bersama. Keempat, cara mempelajari buku teks, DR memilliki minat baca yang pasif, saat siswa aktif membaca juga bisa menambah wawasan dan pengetahuan. Hal ini diperkuat dengan pendapat (Idris, 2017) bahwa dampak negatif pada kurangnya minat siswa dalam membaca buku, diharapkan guru SD dapat menanamkan pengertian terhadap para siswa tentang manfaat membaca buku. Faktor yang berkontribusi besar pada prestasi belajar anak pekerja migran yaitu dengan memiliki kebiasaan belajar yang teratur. Sependapat dengan (Marcus \& Kuncel, 2008) menyatakan bahwa perspektif paling mudah untuk mengonsep kebiasaan belajar sebagai tindakan langsung guna mencapai prestasi.

Pelaksanaan Self management anak pekerja migran sebagai motivator bagi siswa dalam menanamkan pernyataan bahwa dirinya telah memiliki tujuan dan siswa mampu menyelesaikan tugas-tugas untuk mencapai tujuan yang diharapkan. DR memiliki pengaturan diri yang kurang saat belajar di rumah dia cenderung memilih berlama-lama bermain HP dan tidak bergegas belajar pada malam hari, setelah dimarahi oleh Ayahnya dia baru berhenti dan mulai belajar. Hal tersebut di dukung oleh hasil Peneliti dari Ohio State University, (Buente \& Robbin, 2008) menyatakan bahwa sosial media menjadikan seorang pelajar memiliki nilai yang menurun. Anak pekerja migran memiliki tujuan dengan pilihan yang tidak sesuai yang membuat mereka memerlukan bimbingan dari orang lebih mengerti akan hal tersebut. Anak yang pekerja migran dengan prestasi rendah mereka tidak mampu memanfaatkan waktu luangnya dan mengutamakan kepentingan sekolah. Sejalan dengan pendapat (Fachrurroi, Firman, \& Ibrahim, 2018) bahwa siswa yang memiliki kontrol diri yang tinggi mereka akan cenderung berpikiran positif dan mampu bertanggung jawab atas tugasnya sebagai seorang pelajar.

Impliksi kebiasaan belajar dan self management anak pekerja migran terhadap bimbingan dan konseling di sekolah dasar di perlukan untuk membantu perkembangan peserta didik. Hal tersebut sesuai dengan pernyataan bahwa bimbingan dan konseling di sekolah mulai jenjang SD/MI hingga SMA/SMK (Trusty, dkk., 2008). Pernyataan tersebut diperkuat dengan dua peraturan yang melandasi penyelenggaraan bimbingan dan konseling yaitu permendiknas RI No.27 Tahun 2008 terkait standar kualifikasi akademik dan kompetensi konselor dan Permendikbud RI No 111 Tahun 2014 terkait bimbingan dan konseling pada pendidikan dasar dan pendidikan menengah. Berdasarkah hal tersebut maka disusun serangkaian kegiatan bimbingan dan konseling yang tertuang pada lampiran Kemendikbud tersebut dengan harapan mampu meningkatkan mutu BK dalam 
membantu tercapainya perkembangan siswa dan kemandirian serta pengendalian diri siswa. Sependapat dengan (Sugianto, 2013) bahwa bimbingan dan konseling pada pendidikan formal memiliki beberapa layanan salah satunya yaitu layanan responsif yang merupakan pemberian bantuan mengembangkan kepribadian konseli untuk menghadapi kebutuhan \& masalah, yang memerlukan pertolongan segera melalui konseling individual, kelompok, kolaborasi dengan teman, guru dan orangtua dan pihak terkait. Siswa yang memiliki masalah sosial tidak akan memiliki hubungan harmonis serta produktif dengan teman, guru, dan masyarakat.

Beberapa faktor yang memengaruhi pembentukan perilaku sosial anak berlatar belakang keluarga TKW oleh lingkungan keluarga yang kurang baik, kurang kasih sayang dan perhatian dari orangtua. Sejalan dengan pendapat (Putra, 2015) menyebab peserta didik berperilaku agresif, sebagian besar disebabkan oleh karakter individu yang keras dan mereka merasa bahwa yang mereka lakukan adalah kewajaran. Pada bidang karir anak pekerja migran memerlukan dukungan danketerlibatan dari keluarga, dan guru. Sependapat dengan (Putra, 2018) suatu kewajiban keterlibatan orangtua dalam memilih dan menentukan karir anak. Dorongan dan bantuan sekecil apapuan dari orangtua akan menguatkan anak pekerja migran lebih termotivasi dalam belajar. Sependapat dengan (Lestari, 2016) faktor pendukung dan penghambat pendidikan anak TKI dipengaruhi oleh latar belakang, personal dan individu. Hasil penelitian ini diharapkan dapat menambah wacana konselor pada jenjang pendidikan sekolah dasar terkait cara belajar dan self management anak pekerja migran.

\section{SIMPULAN}

Berdasarkan paparan hasil temuan peneliti sesuai dengan fokus penelitian maka disimpulkan sebagai berikut. Terdapat empat aspek kebiasaan belajar yang teridentifikasi pada anak pekerja migran berprestasi rendah di Ponorogo. Keempat aspek tersebut yaitu cara mengikuti pelajaran, meliputi berkonsentrasi, fokus saat di kelas. Cara belajar mandiri diantaranya memanfaatkan waktu luang, menyelesaikan PR, memiliki catatan. Cara belajar kelompok diantaranya pasif dan aktif dalam mengerjakan tugas kelompok. Cara mempelajari buku teks, yaitu minat baca dan mengulang materi. Self management anak pekerja migran terdapat tiga aspek, yaitu aspek pendorong diri, penyusunan diri, pengendalian diri. Pertama aspek pendorong diri, meliputi minat, lama belajar, dan motivasi diri. Kedua, aspek penyusunan diri, meliputi pikiran, tenaga, tempat, dan catatan. Ketiga, aspek pengendalian diri, meliputi disiplin, kemauan, malas, mencari gampangnya saja, dan menunda mengerjakan PR.

Implikasi kebiasaan belajar dan Self Management anak pekerja migran pada empat bidang bimbingan dan konseling, yaitu bidang pribadi mampu mengatur diri kemauan disiplin dan memiliki rasa tanggung jawab. Pada bidang sosial mampu mengembangkan kemampuan bersosialberkomunikasi dengan lingkungannya, dan menjunjung tinggi kebiasaan sopan santun. Konselor membantu siswa untuk memilih dan menentukan karir di masa mendatang sesuai dengan bakat dan minat diri siswa. Bidang terakhir yaitu bidang belajar dengan memberikan layanan bimbingan belajar kepada siswa guna memperoleh kebiasaan belajar yang efektif untuk mengembangkan rasa ingin tahu siswa dalam menambah pengetahuan.

Temuan penelitian dan kajian terhadap data dalam peneltian pada kebiasaan belajar dan self management anak pekerja migran berprestasi rendah dapat memberikan saran yang diharapkan dan bermanfaat bagi berbagai pihak. Siswa diharapkan memiliki kontrol diri, penyusunan diri, pengendalian diri dengan baik. Disarankan agar konselor memiliki kepribadian intelegen, ikut berperan produktif, memiliki kemampuan dalam menanggani masalah dan familiar dengan konseli atau multisumber. Hasil penelitian ini diharapakan dapat menjadi acuan pada peneliti selanjutnya dengan subjek dan sumber yang lebih banyak.

\section{DAFTAR RUJUKAN}

Badan Nasional Penempatan dan Perlindungan Tenaga Kerja Indonesia. (2019). Diambil dari http://www.bnp2tki.go.id/ Buente, W., \& Robbin, A. (2008). Trends in Internet Information Behavior. Journal of the American Society for Information Science, 1-28.

Creswell, J. (2015). Riset Pendidikan Perencanaan, Pelaksaan dan Evaluasi Riset Kualitataif \& Kuantitatif (ke lima). Yogyakarta: Pustaka Pelajar.

Daradal, D. (2010). Pricipal's Adversity Quotient: Style, performance, and Practices. Division of Educational Leadership and Professional Servoces College of Education University of Phillipines.

Fachrurroi., Firman., \& Ibrahim, I. (2018). Hubungan Kontrol Diri dengan Disiplin Siswa Dalam Belajar. Jurnal Neo Konseling, $1(1), 1-6$.

Idris. (2017). Menanamkan Budaya Membaca pada Siswa Sekolah Dasar.

Irachmat, M. R. (2015). Peningkatan Perhatian Siswa pada Proses Pembelajaran Kelas III melalui Permainan Icebreaking di SD Gembongan. Skripsi tidak diterbitkan. Universitas Negeri Yogyakarta, Yogyakarta.

Lestari, T. (2016). Aspirasi Pendidikan dalam Kelauarga TKI di Desa Jangkaran Kecamatan Temon Kabupaten Kulon Progo. Jurnal Kebijakan Pendidikan, 5(1), 59-71.

Limpo, J. N., Oetomo, H., \& Suprapto, M. H. (2013). Pengaruh Lingkungan Kelas terhadap Sikap Siswa untuk Pelajaran Matematika. HUMANITAS, X, 37-48. 
Magfiroh, I., Rahman, U., \& Sulateri, S. (2015). Pengaruh Konsep Diri dan Kebiasaan Belajar terhadap Hasil Belajar Matematika Siswa Kelas VIII SMPN 6 Bontomatene Kepulauan Selayar. MaPan: Jurnal Matematika dan Pembelajaran, 3(1), 103-116.

Putra, A. K. (2018). Peran Orangtua dalam Perencanaan Karir Anak Usia SMP di Dusun Jamburejo. Jurnal Riset Mahasiswa Bimbingan dan Konseling, 4.

Putra, A. R. B. (2015). Peran Guru Bimbingan dan Konseling Dalam Mengatasi Kecenderunngan Perilaku Agresif Peserta Didik di SMKN 2 Palangka Raya. Jurnal Konseling GUSJIGANG, 1(2), 1-7. DOI: https://doi.org/10.24176/jkg.v1i2.406

Trusty, J., Mellin, E. A., \& Herbert, J. T. (2008). Closing Achievement Gaps: Roles and Tasks of Elementary School Counselors. The Elementary School Journal, 108(5), 407-421. https://doi.org/10.1086/589470

Widiarsono. (2017). Smart Study. Jakarta: PT Elex Media Komputindo. 